Full length article

\title{
EFFECTS OF LAND-USE CHANGE ON THE PROPERTIES OF TOP SOIL OF DECIDUOUS SAL FOREST IN BANGLADESH
}

\author{
M. A. Kashem', A. Ahmed', S. Hoque'2 and M. Z. Hossain ${ }^{*}$ \\ 'Department of Botany, University of Dhaka, Dhaka-1000, Bangladesh \\ 2Department of soil, Water and Environment, University of Dhaka, Dhaka 1000, Bangladesh
}

\section{ABSTRACT}

This study examined the effects of land use change on the physico-chemical properties of top soil in the deciduous Sal forest of Bangladesh. Relatively less disturbed Sal (Shorea robusta Roxb. Ex Gaertn.) forest stands and the nearby stands those were converted into Acacia (Acacia auriculiformis Benth.) plantation and pineapple (Ananus comosus (L.) Merr.) cultivation were selected to examine the effects of land use change on soil properties. For each land use type, soil samples were collected from 4 locations, $50 \mathrm{~m}$ distant from each other, as replicates. Soil samples were collected at 0-5, 5-10, and 10-15 cm depths. Soil moisture content, conductivity, pH organic C, total $\mathrm{N}$ and total $\mathrm{P}$ were determined as soil properties. Leaf litter of Sal, Acacia and pineapple was incubation for 90 and 180 days in independent identical soil in order to examine the effects of plant species through leaf litter on the soil chemical nutrient ( $N$ and P) status. Data showed that soil moisture content, conductivity and $\mathrm{pH}$ were significantly affected by land use but not by depth. However, soil organic $C$ was affected by both land-use type $(P<0.02)$ and soil depth $(P<0.003)$, although no significant interactions appeared between these two factors. Soil total $\mathrm{N}$ and $\mathrm{P}$ did not differ between land use types but by depth and, $\mathrm{N}$ and $\mathrm{P}$ contents decreased with the increase of depth. Rates of nutrients ( $N$ and $P$ ) released from Sal, Acacia and pineapple did not differ significantly among them during incubation. Results of the present study reveal that properties of the top soil of the Madhupur Sal forest are different in their responses to the varying land uses. The findings of this study are thus relevant for the sustainable management of the deciduous Sal forest ecosystems.

KEYWORDS: Deciduous forests, land use change, nutrient release, topsoil

*Corresponding author: (Email: zabed@du.ac.bd)

\section{INTRODUCTION}

Forest disturbances and land conversions are regarded as one of the major drivers of soil degradation [1]. Changes in land use are likely to affect soil properties through distribution and supply of soil nutrients [2]. Study on the effect of land use change on the top soil is more relevant as it plays greater role in plants' growth and development by providing nutrients [3]. Moreover, understanding the properties of top soil is important as the depth of top soil has proved a significant parameter in determining soil quality and land productivity $[4,5,6]$. 
The Sal forests dominated by Sal (Shorea robusta Roxb. Ex Gaertn.) in the central plains and north-western regions of Bangladesh are deciduous forests. The Sal forests of Bangladesh are severely impacted by many forms of human induced activities including deforestation, litter collection, plantation and cultivation with introduced plant species [7]. Understanding the physical and chemical properties of forest soil is important because of their influence on productivity and nutrient cycling of the ecosystem [8]. Moreover, adequate knowledge about the effects of landuse changes on soil properties is necessary before taking program like plantation or cultivation of crop in the Sal forests. However, there is limited knowledge on the effects of land-use changes on the properties of soil of Sal forest in Bangladesh. The main objective of this study was to assess and compare the changes in the physicochemical properties of soils and nutrient release rates of litter and explore the relationships among soil properties of the different land use types.

\section{MATERIALS AND METHODS}

\subsection{Site description}

The Sal forest in the Madhupur tract, also known as Madhupur Garh, is situated in the district of Tangail (Figure 1). The forest is moist deciduous in nature and located from $24.30^{\circ}$ to $24.50^{\circ} \mathrm{N}$ and $90^{\circ}$ to $90.10^{\circ} \mathrm{E}$. The annual rainfall of the area is ca. $1800 \mathrm{~mm}, 90 \%$ of which occurs in the period of May through October [9]. The average temperature of the area ranges from 30.3 to $20.9^{\circ} \mathrm{C}$ across the year [10]. Three different land-use types namely natural Sal forest, Acacia plantation and Pineapple cultivation were selected for the collection of soil samples.

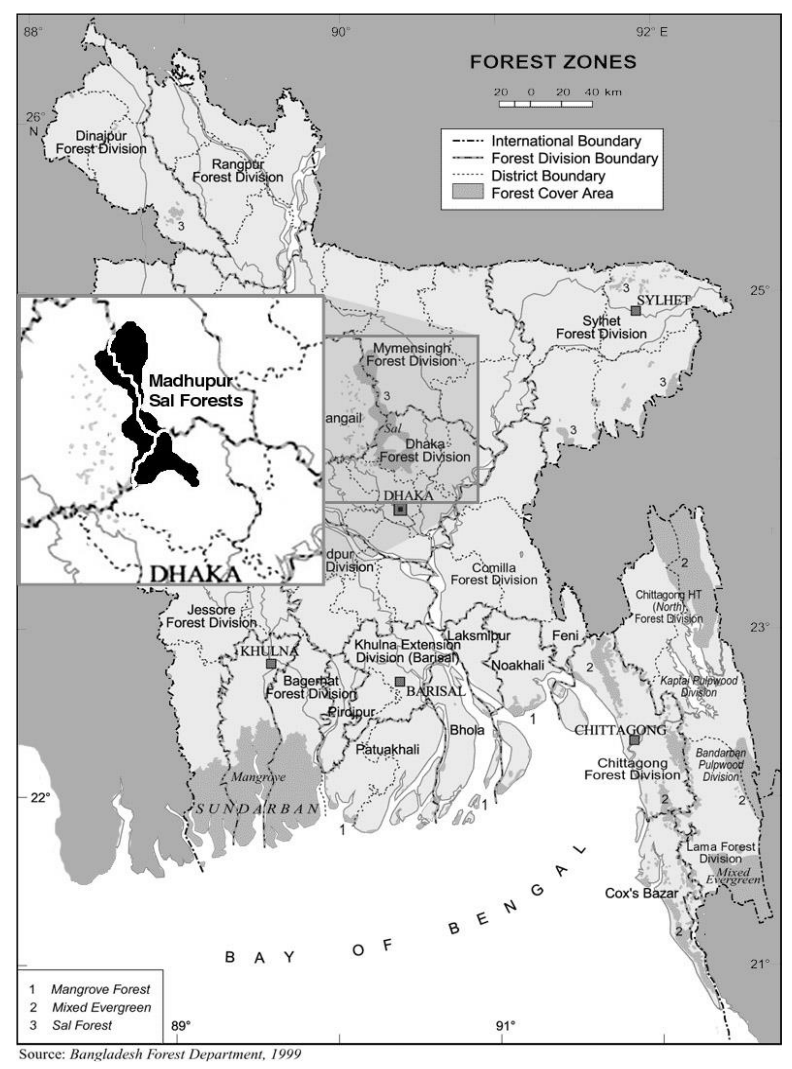

Figure 1: Map of the study area (black shaded) of the Madhupur Sal forest in Bangladesh.

\subsection{Collection and analysis of soil samples}

Soil samples were collected from the sites under the three kinds of land use types. For each land-use type, four locations, $50 \mathrm{~m}$ distant from each other, were selected to collect soil at $0-5,5-10$ and $10-15 \mathrm{~cm}$. Thus, a total of 36 soil samples, each 12 from the three land-use types were selected.

Soil $\mathrm{pH}$ and electrical conductivity were determined in suspension with distilled water with the ratios 2:1 and 5:1 ( $v: w)$, respectively. Soil moisture content was measured by weight loss after drying $10 \mathrm{~g}$ fresh soil at $80^{\circ} \mathrm{C}$ for $24 \mathrm{~h}$. Soil total $\mathrm{N}$ was determined by following the Kjeldahl method [11]. Soil $P$ content was extracted with $\mathrm{HNO}_{3}$ and $\mathrm{HClO}_{4}$ and determined by color development using a spectrophotometer at $440 \mathrm{~nm}$ [12]. Soil 
organic carbon was determined by Walkley and Black method [1 11 .

\subsection{Litter chemistry, decomposition and nutrient release rate}

Three plant species Sal (Shorea robusta), Acacia (Acacia auriculiformis) and Pineapple (Ananus comosus) grown in the forests were selected to collect leaf litter for the analysis of leaf $\mathrm{N}$ and $\mathrm{P}$, decomposition rate and $N$ and $P$ release rate from leaf litter after incubation. Fresh leaves were collected from the field and then brought to the laboratory and then dried at $60^{\circ} \mathrm{C}$ for 24 hours. Soil used for incubation of the litter was collected from the Botanical garden, Department of Botany, University of Dhaka. Soil used in the decomposition study was characterized for chemical properties (pH 7.0, electric conductivity $53.7 \mu \mathrm{s}$, moisture content $20.35 \%$, total N $0.117 \%$ and total $P(0.062 \%)$. Part of the dried leaves of all species was cut into $2 \mathrm{~cm} \times 2 \mathrm{~cm}$ long in size to make the leaves of similar size before incubation. Then 1 $\mathrm{g}$ leaf litter of each of litter species was mixed with $450 \mathrm{~g}$ soil already taken into the pot. The leaves were mixed well with soil using forceps. Pots were then covered by sterilized polythene bag to avoid contamination. Triplicate replications were used for each treatments including control (soil without litter). Autoclaved water was added in such a way that all pot received similar moisture content throughout the period of the experiment. The pots were kept for incubation at room temperature. Samples were collected destructively after 90 days and 180 days for the analysis of rates of mass loss and release of $\mathrm{N}$ and $\mathrm{P}$ into soil. On day after completion of 90 days and 180 days, the un-decomposed leaf litter was collected from the pot and rinsed thoroughly with distilled water to remove soil. Litter was then oven-dried for $24 \mathrm{~h}$ at $60^{\circ} \mathrm{C}$. The mass remaining was then calculated for study of decomposition rate at 90 and 180 days.

\section{RESULTS}

\subsection{Soil physico-chemical properties}

Two-way ANOVA statistics on the effects on landuse type, depth and their interaction on the soil physico-chemical properties are shown in Table 1. Data showed that although soil moisture content, conductivity and $\mathrm{pH}$ were significantly affected only by landuse type, soil organic $C$ content was affected by both landuse type $(P<0.02)$ and soil depth $(P<$ 0.003), nevertheless no significant interactions appeared. Soil total $\mathrm{N}$ and total $\mathrm{P}$ was affected by depth but not by land-use.

Table 1: Overall Two-way ANOVA statistics (F-ratios) of the effects of land-use type, depth and their interaction on the properties of top soil in the Madhupur Sal forest area, Bangladesh.

\begin{tabular}{llll}
\hline Source of variation & $\begin{array}{l}\text { Land-use } \\
\text { types } \\
(\mathrm{df}=2)\end{array}$ & $\begin{array}{l}\text { Depth } \\
(\mathrm{df}=2)\end{array}$ & $\begin{array}{l}\text { Land-use } \\
\times \quad \text { depth } \\
(\mathrm{df}=4)\end{array}$ \\
\hline $\mathrm{pH}$ & $24.30^{* * *}$ & 0.18 & 0.15 \\
Conductivity (us) & $16.29^{* * *}$ & 0.52 & 0.27 \\
Moisture (\%) & $17.84^{* * *}$ & 2.88 & 1.05 \\
Organic C (\%) & $4.48^{*}$ & $7.40^{* *}$ & 0.21 \\
Total N (\%) & 1.38 & $5.45^{*}$ & 1.16 \\
Total P (\%) & 1.50 & $3.72^{*}$ & 1.19 \\
\hline
\end{tabular}

Table 2: Mean values with standard error mean of the physico-chemical properties of soil measured at different depths $(0-5 \mathrm{~cm}, 5-10 \mathrm{~cm}$ and $10-15 \mathrm{~cm})$ in Sal 
forest, Acacia plantation and Pineapple cultivation in the Madhupur Sal forest, Bangladesh

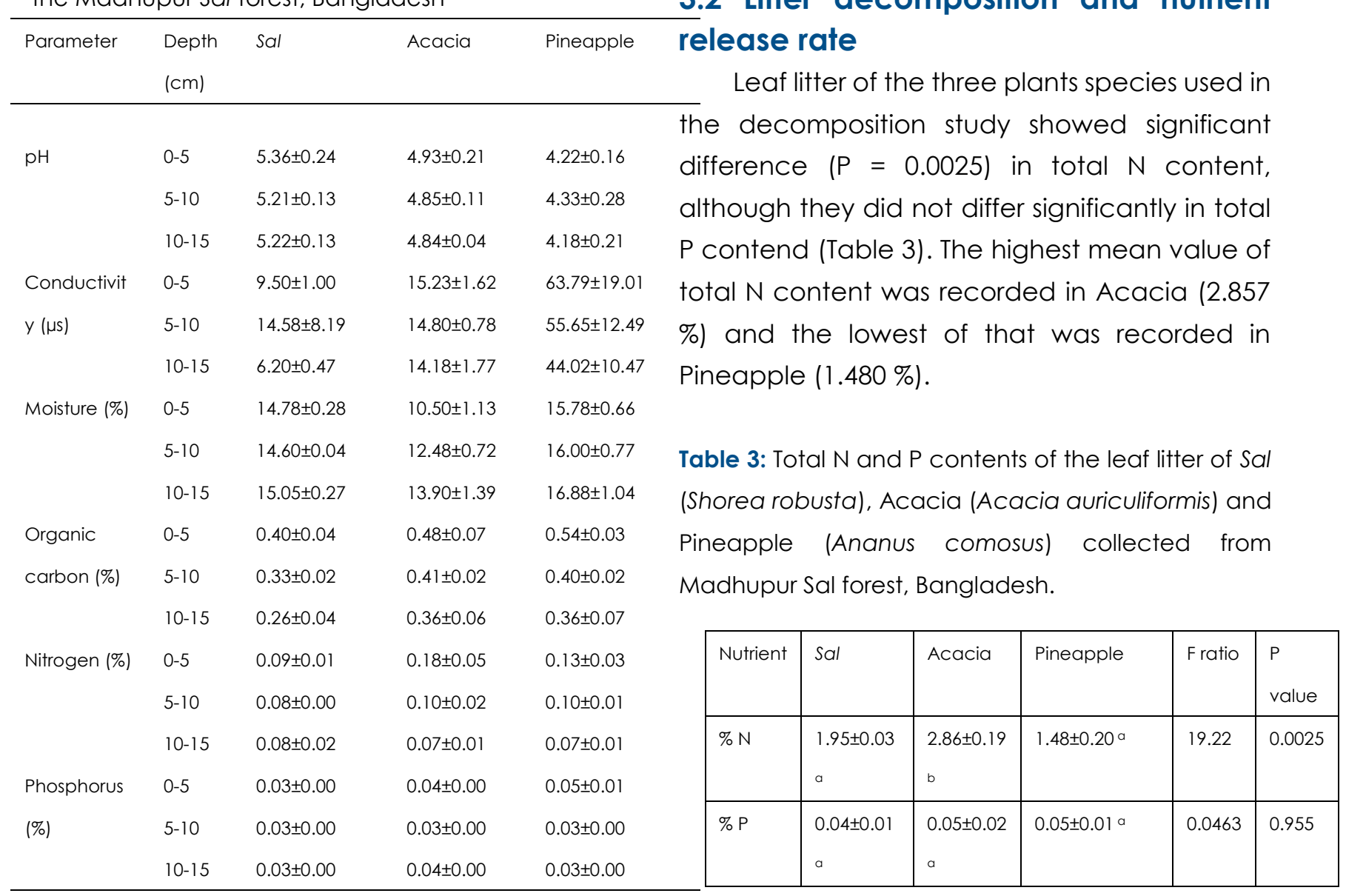

Lowest $\mathrm{pH}$ value was found in the Pineapple cultivation and the highest was found in the Sal forest sites. Highest conductivity value (63.79 $\mathrm{\mu s}$ ) was reported in Pineapple cultivation while the lowest of that was recorded in Sal forest. The Pineapple cultivation also showed the highest moisture content (16.88\%) compared to that in the Acacia plantation and Sal forest sites. Significantly higher value of soil organic $\mathrm{C}$ in the Pineapple cultivation $(0.540 \%)$ was recorded at $0-5 \mathrm{~cm}$ depth and that was lowest in the Sal forest (0.255\%) at $10-15 \mathrm{~cm}$ depth. Soil total $\mathrm{N}$ and $\mathrm{P}$ did not show any significant difference among land-use types they showed significant difference among the different depth. Soil total $\mathrm{N}$ and $\mathrm{P}$ gradually decreased from upper layer $(0-5 \mathrm{~cm})$ to the lower $(10-15 \mathrm{~cm})$ layer.

\subsection{Litter decomposition and nutrient} the decomposition study showed significant difference $(P=0.0025)$ in total $N$ content total $\mathrm{N}$ content was recorded in Acacia $(2.857$ $\%)$ and the lowest of that was recorded in Pineapple ( $1.480 \%$ ).

Table 3: Total $\mathrm{N}$ and $\mathrm{P}$ contents of the leaf litter of Sal

Overall two-way ANOVA statistics showed that soil total $N(\%)$ and $P(\%)$ after incubation with leaf litter were significantly affected only by litter species however mass remaining was by litter species, incubation time and interaction between species and time (Table 4). Mass remaining value was lowest for Pineapple and highest for Acacia at both 90 and 180 days after incubation indicating that Pineapple was the most easily decomposable while Acacia was the most hardly decomposable litter (Table 5). Although addition of leaf litter of Sal, Acacia and Pineapple caused significant increase of total $\mathrm{N}$ and total $\mathrm{P}$ compared to control soil, there were no significant differences among the three litter species (Table 6). 


\section{DISCUSSION AND CONCLUSION}

Soil moisture, conductivity and $\mathrm{pH}$ are found to respond differently to various human induced managements following conversion from natural deciduous forests. Changes in physical properties due to landuse change have been reported by substantial number of studies. Significant difference in soil pH among various landuses has been reported by other studies $[13,14]$.

Table 4: Two-way ANOVA statistics of the effects of litter species, incubation time and their interactions on the mass remaining (g) and soil total $N(\%)$ and $P(\%)$ contents of leaf litter of Sal, Acacia and Pineapple.

The lowest mean $\mathrm{pH}$ value in the Pineapple cultivation might be associated with

\begin{tabular}{llll}
\hline Parameter & Litter & Day & Litter*Day \\
\hline Mass remaining & $55.30^{* * *}$ & $465.18^{* * *}$ & $14.94^{* * *}$ \\
Total N & $3.80^{*}$ & 0.11 & 0.16 \\
Total P & $13.58^{* * *}$ & 0.26 & 0.31 \\
\hline
\end{tabular}

high organic $C$ as found in the present study. Organic $C$ i.e. high organic matter might have been responsible for acidic condition through generation of humic acid in these sites compared to the other land-use types [13]. Although the three landuse types differed significantly among them the overall soil $\mathrm{pH}$ was slightly acidic among the land-use types. This forest was previously reported to exhibit low $\mathrm{pH}$ value $[15,16]$. Significant difference in the soil moisture content found in the present study might be related to the identity of the dominant tree species in the land types. The lowest soil moisture content found in Acacia plantation might be due to the reason that this fast growing legume species might require more moisture for maintaining its fast growth compared to other species. Further, it is also likely that high moisture content in the Pineapple cultivation might be associated with watering by the farmers during the cultivation season of this crop.

Like many other studies $[13,17,18]$, this study also reported that soil organic C significantly differed among the landuses. Cultivation of Pineapple and plantation of fast growing Acacia might be related with the higher production of organic matter in these two land use types than that found in the Sal forest which is a mature and stable forest ecosystem. Soil organic C content declined with the increase of soil depth across landuse types. This could be due to higher accumulation of plant litter in the upper surface than the lower one. Result of the present study is thus consistent with that of other studies [19].

Table 5: Mean values with SEM of the mass (g) remaining of the litter species at different time during incubation. Different letters indicate significance of difference.

\begin{tabular}{llll}
\hline $\begin{array}{l}\text { Incubation } \\
\text { time (day) }\end{array}$ & Sal & Acacia & Pineapple \\
\hline Initial & $1.00 \pm 0.00$ a & $1.00 \pm 0.00^{a}$ & $1.00 \pm 0.00$ a \\
90 & $0.63 \pm 0.04^{a}$ & $0.69 \pm 0.01^{a}$ & $0.33 \pm 0.02^{b}$ \\
180 & $0.43 \pm 0.02^{a}$ & $0.49 \pm 0.04^{a}$ & $0.23 \pm 0.04^{b}$ \\
\hline
\end{tabular}

Mass remaining gradually decreased from the starting time (initial) to 180 days through 90 days. Acacia and Pineapple leaf showed the highest and the lowest, respectively mass remaining at both 90 and 180 days during incubation. This result thus indicated that Pineapple and Acacia were most easily and hardly, respectively, decomposable litter used in the present study. 
On day 90, Pineapple leaf litter showed the lowest mass remaining i.e. highest mass loss rate and the highest soil $\mathrm{N}$ and $\mathrm{P}$ release rates while Acacia leaf litter showed the lowest mass loss rate and the lowest $\mathrm{N}$ and $\mathrm{P}$ release rates (Table 5 and 6 ) indicating that mass loss rate and litter quality are positively correlated. Other studies also reported similar results. Highquality litter ( $\mathrm{N}$-rich) enhances decomposition rate at an early stage $[20,21,22]$ because such litter provides readily available $\mathrm{C}$ for microbes; nutrients released from soil consequently promote microbial growth and activity. Nitrogen content of plant tissues is important in controlling the rate of decomposition according to some studies[23,24]. However, on day 180 , mass remaining did not correlate with the $\mathrm{N}$ and $\mathrm{P}$ release rates indicating that other factors phenolic compounds in the leaf litter tissues and microbial community composition might be related with the litter decomposition rate [15].

Table 6: Mean values with SEM of the effects of litter species on soil total $\mathrm{N}(\%)$ and total $\mathrm{P}(\%)$ at 90 days and 180 days after incubation. Different letters indicate significance of difference.

\begin{tabular}{|c|c|c|c|c|c|}
\hline & Day & Control & Sal & Acacia & Pineapple \\
\hline \multirow[t]{2}{*}{$N$} & 90 & $0.12 \pm 0.02^{a}$ & $0.15 \pm 0.00 a$ & $0.14 \pm 0.00 a$ & $0.15 \pm 0.00 a$ \\
\hline & 180 & $0.12 \pm 0.02 a$ & $0.15 \pm 0.00 a$ & $0.15 \pm 0.00 a$ & $0.15 \pm 0.00 a$ \\
\hline \multirow[t]{2}{*}{$P$} & 90 & $0.06 \pm 0.00^{a}$ & $0.09 \pm 0.00^{b}$ & $0.08 \pm 0.00^{\mathrm{b}}$ & $0.09 \pm 0.01^{b}$ \\
\hline & 180 & $0.06 \pm 0.00^{a}$ & $0.08 \pm 0.00 \mathrm{ab}$ & $0.08 \pm 0.00^{b}$ & $0.09 \pm 0.01^{b}$ \\
\hline
\end{tabular}

The result that the three land-use types in Madhupir Sal forest did not differ in soil $\mathrm{N}$ and $\mathrm{P}$ content may be due to the reason that in spite of the difference in litter $\mathrm{N}$ content decomposition of the leaf litter is not determined by the leaf $\mathrm{N}$ content in the long run in the Sal forest. Land use change was also reported not to affect significantly soil total $\mathrm{N}$ and total P [24].The reason for low responses of the soil chemical properties including total $\mathrm{N}$ and $P$ to different management activities has been ascribed to the nature of the parent material of the soil. Andosols have been reported to show slow response to the different management activities [26]. Soils with rich in pumice and allophanic are more resistant to degradation due different management systems[27]. The soils of the Madhupur Sal forest have been identified as Red-Brown Terrace soils and as Orthi-Ferric Acrisols by the FAO-UNESCO system[28]. Acidic nature of these soils might be related with the less availability of the $N$ and $P$. However, higher content of soil total $N$ and $P$ in the uppermost $(0-5 \mathrm{~cm})$ soil layer might be due to the highest accumulation of litter in the upper layer. Overall, result of the present study implies that properties of the top soil of the Madhupur Sal forest are different in their response to the varying managements. The findings of the present study are thus relevant for the sustainable management of the forests ecosystems through conversion into other landuse/cover.

Acknowledgements: The authors are thankful to the Centre for Advanced Studies and Research in Biological Sciences, University of Dhaka, Bangladesh for a partial financial support to conduct this study. The authors are also thankful to Mr. Md. Mohsin Akber, the then M.S. student of the Department of Botany, University of Dhaka for help in collecting samples from the field. 


\section{References}

[1] P.A. Matson, K.A. Lohse, S.J. Hall, The globalization of nitrogen deposition: consequences for terrestrial ecosystems. Ambio. 31 (2002)113-119

[2] D. Murty, M.U.F. Kirschbaum, R.E. Mcmurtrie, H. Mcgilvray, Does conversion of forest to agricultural land change soil carbon and nitrogen? A review of the literature, Global Change Biology 8 (2002) 105-123

[3] X.M. Fang, F.S. Chen, S.Z. Wan, Q.P. Yang, J.M. Shi, Top soil and deep soil organic carbon concentration and stability vary with aggregate size and vegetation type in subtropical China. PLOS ONE 10(9): (2015) e0139380.doi:10.1371/journal.pone.0139380.

[4] N. Brunel, F. Meza, R. Ros, F. Santibáñez, Effects of topsoil loss on wheat productivity in dryland zones of Chile. J. Soil Sci. Plant Nutr. 11 (2011) 129-137

[5] R.J. Harper, M. Tibbett, The hidden organic carbon in deep mineral soils. Plant Soil 368 (2013) 641-648

[6] C. Rumpel, L. Koegel-Knabner, Deep soil organic matter-a key but poorly understood component of terrestrial C cycle. Plant Soil 338 (2011) 143-158

[7] K.B.S. Rasheed, Participatory forestry as a strategy for reforestation in Bangladesh. Geo Journal 37 (1995) 39-44

[8] S.G. Baer, J.M. Blair, S. Collins., A.K. Knapp, Soil resources regulate productivity and diversity in newly established tallgrass prairie. Ecology 84 (2003) 724-735

[9] E.B. Manalo, Agro-climatic survey of Bangladesh. BRRI/IRRI. Los Banos, Leguna, Philippines (1976)

[10] C.Q. Ghani, A. Alim, P.R. Stevens, Rehabilitation and land use planning of Sal forests, parts I, II, and III. FAO/UNDP Project 85/085, Assistance to the forestry sector, Phase II, Dhaka, FAO (1990)

[11] C.A. Black, Methods of soil and plant analysis. Part I and II. American Society of Agronomy (1965)
[12] M.L. Jackson. Soil Chemical Analysis. PrenticeHall. NJ (1958)

[13] V. Agoumé, A.P. Birang, Impact of Land-use Systems on some Physical and Chemical Soil Properties of an Oxisol in the Humid Forest Zone of Southern Cameroon. TROPICULTURA 27 (2009) $15-20$

[14] S.Y. Korkanc, N. Ozyuvaci, A. Hizal, Impacts of land use conversion on soil properties and soil erodibility. Journal of Environmental Biology 29 (2008) 363-370

[15] M.Z. Hossain, A. Okubo, S. Sugiyama, Effects of grassland species on decomposition of litter and soil microbial communities. Ecol Res. 25 (2010) 255-261

[16] A.E. Hoque, A.K.M. Nazrul-Islam, S.M.I. Hoque, Seasonal variation of edaphic features of Madhupur Sal forest, Bangladesh. Ecoprint 15 (2008) 7-14

[17] F. Xiangmin, W. Qingli, Z. Wangming, Z. Wei, W. Yawei, N. Lijun, D. Limin, Land use effects on soil organic carbon, microbial biomass and microbial activity in Changbai Mountains of Northeast China. Chin. Geogra. Sci. 24 (2014) 297-306

[18] G. Guggenberger, B.T. Christensen, W. Zech, Land use effects on the composition of organic matter in particle-size separates of soil: I Lignin and carbohydrate signature. Eur. J. Soil Sci. 45(1994) 449-458

[19] T. Chibsa, T.A. Asefa, Assessment of Soil Organic Matter under Four Land Use Systems in the Major Soils of Bale Highlands, South East Ethiopiab. Factors Affecting Soil Organic Matter Distribution. World Applied Sciences Journal 6 (2009) 1506-1512

[20] Z. Koukoura, A.P. Mamolos, K.L. Kalburtji, Decomposition of dominant plant species litter 
in a semi-arid grassland. Appl. Soil Ecol.23 (2003) 13-23

[21] T. Teklay, A. Nordgren, G. Nyberg, A. Malmer, Carbon mineralization of leaves from four Ethiopian agroforestry species under laboratory and field conditions. Appl. Soil. Ecol. 35 (2007) 193-202

[22] M.Z. Hossain, S. Sugiyama, Effects of chemical composition on the rate and temporal pattern of decomposition in grassland species leaf litter. Grassland Science 54 (2008) 40-44

[23] W.P.K. Findlay, Studies in the physiology of wood destroying Fungi. The effect of nitrogen content upon the rate of decay of timber. Annals of Botany 48, (1934) 109-117

[24] H.S. Miller, F.B. Smith, P.E. Brown, The rate of decomposition of various plant materials in soils.

J. American Soc. Agr. 28 (1936) 914-923
[25] V. Geissen, R. Sánchez-Hernández, C. Kampichler, R. Ramos-Reyes, A. SepulvedaLozada, S. Ochoa-Goana, B.H.J. de Jong, E. HuertaLwanga, S. Hernández-Daumas, Effects of land-use change on some properties of tropical soils - An example from Southeast Mexico. Geoderma 151 (2009) 87-97

[26] D. Aran, M. Gury, E. Jeanroy, Organometallic complexes in an Andosol: a comparative study with a Cambisol and Podzol. Geoderma 99 (2001) 65-79

[27] W.E. Cotching, R.F. Allbrook, H.S. Gibbs, Influence of maize cropping on the soil structure of two soils in the Waikato district, New Zealand. New Zealand J.Agr. Res. 22 (1979) 431-438

[28] K.R. Islam, R.R. Weil, Land use effects on soil quality in a tropical forest ecosystem of Bangladesh. Agriculture, Ecosystems and Environment 79 (2000)9-16 